\title{
Correction to: New approaches to symptomatic treatments for Alzheimer's disease
}

Jeffrey Cummings

Correction to: Mol Neurodegeneration 16, 2 (2021)

https://doi.org/10.1186/s13024-021-00424-9

The original article [1] contains an error in the spelling of Masupirdine.

All instances of 'Masuperdine' should thus be considered as 'Masupirdine'.

Published online: 01 April 2021

\section{Reference}

1. Cummings J. New approaches to symptomatic treatments for Alzheimer's disease. Mol Neurodegeneration. 2021;16:2 https://doi.org/10.1186/s13024021-00424-9.

(c) The Author(s). 2021 Open Access This article is licensed under a Creative Commons Attribution 4.0 International License, which permits use, sharing, adaptation, distribution and reproduction in any medium or format, as long as you give appropriate credit to the original author(s) and the source, provide a link to the Creative Commons licence, and indicate if changes were made. The images or other third party material in this article are included in the article's Creative Commons licence, unless indicated otherwise in a credit line to the material. If material is not included in the article's Creative Commons licence and your intended use is not permitted by statutory regulation or exceeds the permitted use, you will need to obtain permission directly from the copyright holder. To view a copy of this licence, visit http://creativecommons.org/licenses/by/4.0/. The Creative Commons Public Domain Dedication waiver (http://creativecommons.org/publicdomain/zero/1.0/) applies to the data made available in this article, unless otherwise stated in a credit line to the data. 